удК 667.5:655.3.022.63

\title{
ДОСЛІДЖЕННЯ ФАКТОРІВ ВПЛИВУ НА ПІДГОТОВКУ ФАРБИ ДЛЯ ОФСЕТНОГО СПОСОБУ ДРУКУ
}

\author{
( Т. А. Роїк, д.т.н., професор, О. Ю. Орлик, магістрантка, \\ НТУУ «КПІ», Київ, Україна
}

\begin{abstract}
В данной статье представлен анализ динамики развития офсетных красок, проведен патентный поиск глубиной

15 лет. Рассмотрен процесс подготовки краски для офсетной печати, определены и систематизированы основные факторы влияния на качество подготовки краски для офсетной печати. Представлено причинно-следственную диаграмму.
\end{abstract}

Analyses the development of offset printing inks has been presented in this article. The patent search has carried out of 15 years depth. The main factors of preparation offset printing inks quality have been defined and systematized.

The diagram as a technological operation of cause-sequent connection has been formed.

\section{Постановка проблеми}

Офсетний друк на сьогоднішній день $€$ загальновизнаним промисловим способом друку, що забезпечує найвищу якість різноманітної поліграфічної продукції [1]. Основні переваги офсетного друку, порівняно з іншими способами, такі: впровадження досить гнучких і ефективних варіантів формного виробництва; поліпшення якості і поява нових витратних матеріалів - паперу, фарб, офсетних гумотканинних полотен і формних пластин; наявність високопродуктивного та технологічно гнучкого друкарського обладнання; висока якість відтворення текстової та графічної інформації; інтенсивне використання електронної, лазерної та обчислювальної техніки на всіх стадіях підготовки видання до друку і протягом друкарського процесу; широке впровадженням систем стандартизації та оптимізації [1]. Цей спосіб друку став еталоном якості завдяки тому, що в традиційному офсетному друці необхідно дотримання ряду загальних технологічних умов. Одна 3 яких це - правильно підібрати та підготувати компоненти системи задруковуваний матеріал-фарба-друкарська форма-зволожувальний розчин. Для отримання якісних відбитків офсетні друкарські фарби повинні мати певні друкарські властивості і відповідати ряду технологічних вимог, окрім цього розроблений процес повинен сприяти підвищенню продуктивності технологічного процесу за рахунок впровадження автоматизації та стандартизації системи підготовки та подачі фарби до друку, тому розробка процесу підготовки фарб для офсетного друку є актуальним 
завданням і потребує виконання комплексу досліджень.

\section{Аналіз попередніх досліджень}

у багатьох публікаціях, зокрема, у роботі [1] наголошується на тому, що використання офсетного друку забезпечує високу якість відтворення продукції, а також характеризується високим рівнем автоматизації виробництва з широким впровадженням систем оптимізації та стандартизації технологічного процесу.

У роботі [2], досліджується склад та структура друкарської фарби, встановлені основні властивості фарби та ї вплив на якість відтворення поліграфічного відбитку та технологічний процес друку. Проведено класифікацію фарб залежно від складу та способу друку.

Автори робіт $[3,4]$ розглядають процес підготовки фарби до друку, складання рецептури та приготування фарби спеціального кольору з вибором та обґрунтуванням необхідного обладнання та контрольновимірювальних засобів. Крім того, останнім часом все частіше офсетним друкарням доводиться вирішувати задачу друку офсетними фарбами зі спеціальними оптичними властивостями в поєднанні з різними задруковуваними матеріалами [5].

Також проводилися дослідження структури ринку витратних матеріалів України, шляхом проведення анкетування [6], визначено основні проблеми та перспективи поліграфічної галузі.
Аналіз робіт з розглядуваної теми показав, що питання оптимізації процесу підготовки фарби для офсетного друку, що безпосередньо впливає на якість друкованої продукції, $є$ актуальним завданням, що потребує детального дослідження та формування системного підходу для його вирішення.

\section{Мета роботи}

Метою даної роботи $€$ аналітичне дослідження офсетних фарб і їх підготовки до друку, визначення та систематизація факторів впливу на якість підготовки фарби для офсетного друку.

\section{Результати проведених досліджень}

Друкарська фарба - це складна колоїдна система, твердою фазою якої є високодисперсні пігментні частинки, які рівномірно розподілені і стабілізовані у середовищі рідкої в'яжучої речовини [2]. Сучасна друкарська фарба повинна володіти цілим комплексом суперечливих властивостей, які важко сумістити в одній фарбі: міцність до стирання, висока швидкість закріплення на задруковуваному матеріалі, висока в'язкість і низька липкість, відсутність відмарювання у стосі, стабільність фарби у друкарській машині. Пігменти забезпечують, головним чином, оптичні характеристики фарб, крім того впливають на їх фізико-хімічні властивості. В'яжучі речовини надають фарбі друкарських властивостей [2].

Отже, основними завданням, які вирішуються на сьогоднішній 
день є вдосконалення складу, структури офсетних фарб, розроблення оптимальних методів і засобів їх підготовки, контролю та використання в поліграфічній галузі.

Основною частиною роботи було проведення патентного пошуку за допомогою веб-ресурсів (http://ep.espacenet. i http://www1.fips.ru), розроблено регламент пошуку, який відображає предмет і зміст пошуку, мету (аналізувати тенденцію розвитку фарб для офсетного друку), ретроспективність 15 років, країни - Японія, США, Китай, Німеччина, Франція. Предмет пошуку складав такі питання: склад офсетних фарб, способи та особливості використання фарб, обладнання та матеріали, для яких використовуються офсетні фарби, методи та засоби контролю властивостей фарб. При аналізі патентної інформації було опрацьовано 72 патенти. Визначено таке співвідношення знайдених патентів відповідно до тематики пошуку:

- склад офсетної фарби, вплив складу та домішок на її властивості - 58,3 \%;

- технологія підготовки та нанесення фарби - 27,7 \%;

- обладнання - 7,1\%;

- методи та засоби контролю - 6,9 \%.

Збільшення кількості публікацій патентів за останні роки свідчить про стрімкий розвиток офсетного способу друку і офсетної друкарської фарби як складової цього процесу. Значна частина публікації патентів присвячена вдосконаленню складу фарб, що сприяє покра- щенню їх характеристик, економічності та екологічності процесу створення та використання фарб. Інша частина патентів присвячена використанню різних домішок для забезпечення необхідних властивостей фарб при їх використанні для різного обладнання та задруковуваних матеріалів. В останні роки збільшується кількість публікації патентів, присвячених програмному забезпеченню, методам та засобам контролю властивостей офсетних фарб, що свідчить про актуальність дослідження цих питань.

На підставі аналізу фахової науково-технічної літератури, періодики та інтернет-ресурсів визначено основні вимоги, які висуваються до поліграфічного відбитку, а саме: точність відтворення оригіналу; яскравість і насиченість; стійкість до сонячного світла, вологи, механічних пошкоджень в процесі експлуатації. Окрім того, офсетні фарби повинні мати цілий комплекс друкарсько-технічних властивостей: відповідати типу і конструкції друкарського обладнання, швидкості друкування та якості матеріалу.

Процес підготовки фарби для офсетного друку передбачає виконання наступних функцій: вхідний контроль якості фарби; складання колірних рецептур і безпосереднє приготування фарби; підбір фарб для конкретних задруковуваних матеріалів 3 урахуванням їх сумісності та забезпечення необхідних споживчих властивостей продукції; використання домішок для коригування властивостей друкарської фарби; 


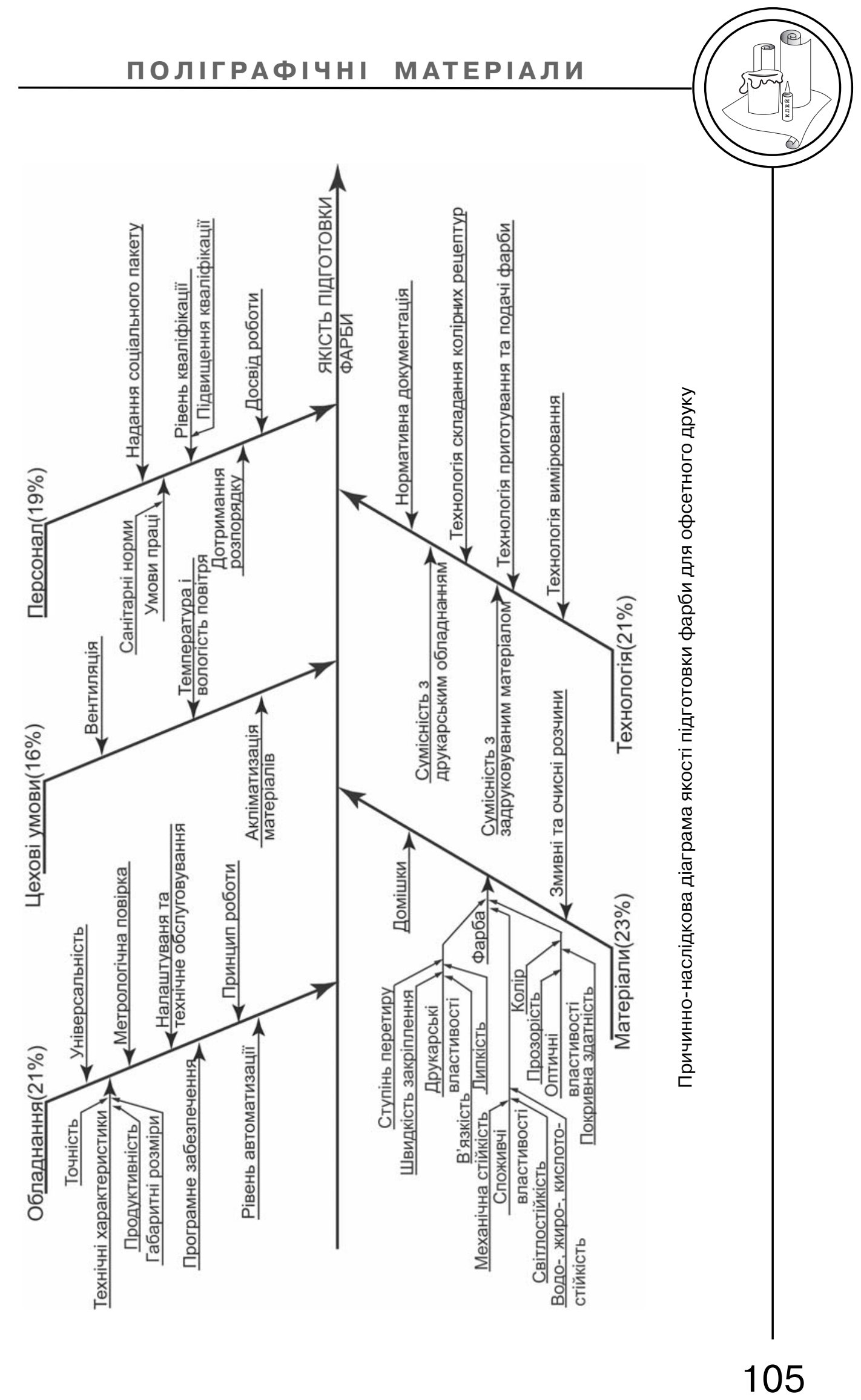


коригування друкарської фарби, враховуючи експлуатаційні характеристики друкарської машини; дотримання графіка, що позв'язує підготовку фарби з графіком роботи і налаштуваннями друкарської машини.

При виконанні досліджень було розроблено та побудовано причинно-наслідкову діаграму (див. рис.). Побудована діаграма Ісікави дозволяє передбачити можливі причини неякісного виконання операції, що в подальшому впливає на весь технологічний процес.

Як видно з рис., основними факторами, які вливають на якість проведення даної технологічної операції є: матеріали, що використовуються, технологія підготовки фарби, обладнання, персонал та цехові умови. Для визначення вагомості впливу кожного із факторів було проведено експертне дослідження методом попарного порівняння, та встановлено, що найвагоміший вплив на якість підготовки фарби для офсетного друку, за результатами опитування експертів, мають 3 фактора: матеріали, технологія та обладнання.

Врахування даних факторів покращує якість проведення операції підготовки фарби для офсетного друку, сприяє використанню оптимальних методів і засобів контролю та корегування властивостей друкарської фарби, що сприяє підвищенню якості друкованої продукції.

\section{Висновки}

В результаті проведених аналітичних досліджень та патентного пошуку, глибиною 15 років, можна стверджувати, що розвиток офсетного друку та офсетних фарб, як складової цього процесу, стрімко розвивається у напрямку підвищення продуктивності технологічного процесу та якості поліграфічного відбитку, і оптимізація процесу підготовки фарби для офсетного друку є невід'ємною частиною цього процесу.

За результатами проведеного аналізу визначено ряд основних факторів, що впливають на процес підготовки фарби для офсетного друку, їх відображено на причинно-наслідковій діаграмі.

Подальші дослідження будуть спрямовані на дослідження та виявлення оптимальних методів, засобів контролю та коригування властивостей друкарської фарби та розроблення детального алгоритму підготовки фарби для офсетного друку.

1. Стефанов С. Основные способы печати как база полиграфических технологий [Електронний ресурс від 29 жовтня 2004 р.] / Стефан Стефанов. - Режим доступу : URL : http://publish.ruprint.ru/stories/2/140_1.php. 2. Поліграфічні матеріали / Під ред. Е. Т. Лазаренка. - Львів : Афіша. 2001. - 327 с. 3. М. Синяк. Воспроизведение цвета в лабораторных условиях / М. Синяк, Д. Лаконкин // КомпьюАрт. - 2007. - № 3. - С. 16-22. 4. Денисов А. Красочная лаборатория : обзорная экскурсия / А. Денисов // КомпьюАрт. - 2010. - № 12. - С. 24-32. 5. Офсетные краски со специальными свойствами // КомпьюАрт. - 2007. - № 5. - С. 26-30. 6. Зайце- 
ва О. Деякі проблеми ринку витратних матеріалів для поліграфії / О. Зайцева // Друкарство. - 2003. - № 1. - С. 74-77.

1. Stefanov S. Osnovnye sposoby pechati kak baza poligraficheskih tehnologij [Elektronnyi resurs vid 29 zhovtnia 2004 r.] / Stefan Stefanov. Rezhym dostupu : URL : http://publish.ruprint.ru/stories/2/140_1.php. 2. Polihrafichni materialy / Pid red. E. T. Lazarenka. - Lviv : Afisha. - 2001. 327 s. 3. M. Sinjak. Vosproizvedenie cveta v laboratornyh uslovijah / M. Sinjak, D. Lakonkin // Komp'juArt. - 2007. - № 3. - S. 16-22. 4. Denisov A. Krasochnaja laboratorija : obzornaja jekskursija / A. Denisov // Komp'juArt. 2010. - № 12. - S. 24-32. 5. Ofsetnye kraski so special'nymi svojstvami // Komp'juArt. - 2007. - № 5. - S. 26-30. 6. Zaitseva O. Deiaki problemy rynku vytratnykh materialiv dlia polihrafii / O. Zaitseva // Drukarstvo. - 2003. № 1. - S. 74-77.

Рецензент - В. Ф. Морфлюк, д.т.н., професор, НТУУ «КП।»

Надійшла до редакції 17.12.12 